\title{
Mineral Analysis in the Amniotic Fluid of Gaddi Sheep during Different Stages of Gestation
}

Parul Shukla, Rajesh Rajput

10.18805/IJAR.B-4477

\begin{abstract}
Background: Amniotic fluid surrounds the fetus and is considered as an important source of certain trace elements essential for fetal tissue growth and metabolism. The concentration of these trace elements in amniotic fluid changes with the progression of gestation. The objective of the present study was to evaluate the concentration of some micro and macro minerals in the amniotic fluid of Gaddi sheep and their relation to fetal age and weight.

Methods: Amniotic fluid was collected from fifty normal gravid uteri for mineral analysis. The foetii were weighed and their crown rump length was measured and then they were divided into four groups i.e. group I (31-60 days), group II (61-90 days), group III (91-120 days) and group IV (121-till term) on the basis of their gestational age.

Result: The mean concentration of sodium and potassium showed a declining trend with the progression of gestation. The level of chloride decreased and that of phosphorus increased significantly from group III to IV. Statistical analysis revealed no significant variation in the concentration of copper among different age groups. Significant correlation was observed between the concentration of minerals and fetal age and fetal weight. Based on the changes in the concentration of minerals in the amniotic fluid, it may be possible to detect the early deviations in the metabolism and thereby appropriate farm management practices could be adopted.
\end{abstract}

Key words: Amniotic fluid, Foetii, Gestation, Gaddi sheep, Mineral.

\section{INTRODUCTION}

Amniotic fluid, which is swallowed by the developing fetus, is an important source of certain minerals and trace elements available for fetal absorption and fetal growth (Jalali and Koski, 2018). These trace elements in amniotic fluid are components of numerous regulatory enzymes and hormones essential for division and differentiation of fetal cells (Lewicka et al. 2017). The concentration of various minerals and elements in amniotic fluid change over the course of pregnancy, with gestational age and fetus growth (Suliburska et al.2016). Gaddi sheep is an important livestock breed of northern temperate region of India. Limited study has been done on the foetal fluid of Gaddi sheep (Shukla et al. 2019; Shukla and Rajput, 2020). The aim of the present study was to evaluate the concentration of some micro and macro minerals in the amniotic fluid and their relation to fetal age and fetal weight.

\section{MATERIALS AND METHODS}

This study was conducted at Department of Veterinary Anatomy, Chaudhary Sarwan Kumar Himachal Pradesh Krishi Vishwavidyalay, Palampur from 2015 to 2019. Fifty normal gravid genetalia were collected from local slaughter houses located in and around Palampur (Himachal Pradesh) from apparently healthy pregnant Gaddi sheep. $10 \mathrm{ml}$ of amniotic fluid was collected in labelled plastic tubes after puncturing the amniotic sac. The collected samples were stored at $-18^{\circ} \mathrm{C}$. The foetal membranes were separated and each foetus was weighed in grams on analytical balance (Table 1). The approximate age was computed using the formula: $Y=2.74 X+30.15$ (Gall et al.1994) where ' $Y$ ' is the
Department of Veterinary Anatomy, College of Veterinary and Animal Sciences, Chaudhary Sarwan Kumar Himachal Pradesh Agriculture University, Palampur-176 062, Himachal Pradesh, India.

Corresponding Author: Parul Shukla, Department of Veterinary Anatomy, College of Veterinary and Animal Sciences, Chaudhary Sarwan Kumar Himachal Pradesh Agriculture University, Palampur176 062, Himachal Pradesh, India. Email: kgobebg@unisa.ac.za

How to cite this article: Shukla, P. and Rajput, R. (2021). Mineral Analysis in the Amniotic Fluid of Gaddi Sheep during Different Stages of Gestation. Indian Journal of Animal Research. DOI: $10.18805 /$ IJAR.B-4477.

Submitted: 08-04-2021 Accepted: 05-07-2021 Online: 02-08-2021

developmental age of foetus in days and ' $X$ ' is the crownrump length in $\mathrm{cm}$. The gestation period was divided into four groups according to age of foetus viz. group I (30-60 days), group II (61 - 90 days), group III (91 - 120 days) and group IV (120 days to term).

Different macro (magnesium and calcium) and micro (iron, copper and zinc) minerals were estimated by atomic absorption spectrophotometer and the values of sodium and potassium were estimated by flame photometry (Mediflame Systronics Flame Photometer-127). Data was statistically analysed by one way analysis of variance using SPSS ver. $17.0(P<0.05)$.

\section{RESULTS AND DISCUSSION}

In this study the mean concentration of sodium in the amniotic fluid of Gaddi sheep decreased non significantly $(p<0.05)$ from group I to group III and then remained same 
in group IV of gestation (Table 2). Aidasani et al. (1993) stated that the mean concentration of sodium was $37.24 \pm$ $3.89 \mathrm{mEq} / \mathrm{L}$ in the amniotic fluid of goat. The significant negative correlation was observed between sodium concentration and foetal weight in group II (Table 4). However, non significant negative correlation was observed between the concentration of sodium and the age of foetii and between sodium concentration and foetal weight in group III vs IV and in group I and III (Table 3,4), respectively. The average value of potassium decreased significantly from group I to group III and increased in group IV of gestation similar to findings of Prestes et al. (2001) in sheep and Khadjeh et al. (2007) in goats. The mineralocorticoid activity due to intrauterine fetal maturity acted on fetal kidneys, which was believed to be responsible for increasing potassium and decreasing sodium concentrations in fetal urine by same researchers. The correlation coefficient was highly significant between the concentration of potassium and the age of foetii in group II vs III and negative non significant in group II vs IV and III vs IV. The correlation coefficient between potassium concentration and foetal weight was negative in group II and IV, although it was non significant (Table 4).

The mean concentration of chloride remained consistent in group I and II of gestation, increased slightly in group III and then decreased significantly in group IV of gestation. Similar observations were made by Prestes et al. (2001) in sheep and Khadjeh et al. (2007) in goat. The significant positive and negative correlation was observed between concentration of chloride and foetal weight in group I and group II of gestation respectively (Table 4). However, correlation observed between the concentration of chloride and the age of foetii was negative and non significant in groups I vs III, II vs III and III vs IV (Table 3).

Table 1: Age and weight of the foetus used in the study.

\begin{tabular}{lcc}
\hline Group & $\begin{array}{c}\text { Age } \\
\text { (days) }\end{array}$ & $\begin{array}{c}\text { Weight of foetus }(\mathrm{g}) \\
-(\text { mean } \pm \text { S.E) }\end{array}$ \\
\hline Group -I & $30-60$ & $13.46 \pm 0.45$ \\
Group-II & $61-90$ & $152.69 \pm 2.35$ \\
Group-III & $91-120$ & $489.89 \pm 1.25$ \\
Group-IV & 121 -till term & $1337.77 \pm 6.48$ \\
\hline
\end{tabular}

Calcium concentration did not vary significantly among different groups of gestation. The correlation in the concentration of calcium and foetal age was highly significant in group I vs II and negatively non significant in groups I vs IV, II vs IV and III vs IV. Also negative non significant correlation was observed between calcium concentration and foetal weight in group II and III of gestation.

Phosphorus concentration did not vary significantly from group I to group III and then it increased significantly in group IV of gestation. Aidasani et al. (1993) reported that the average concentration of phosphorus in the amniotic fluid of goat was $4.31 \pm 1.31 \mathrm{mg} / \mathrm{dl}$. The negative non significant correlation was observed between its concentration and foetal age throughout gestation (Table 3 ) and between its concentration and foetal weight in group II and group IV of gestation (Table 4).

The mean concentration of copper remained nearly consistent throughout gestation. In humans, fetal copper concentration reportedly increased or remained stable throughout gestation (Hefnawy et al.2011) where as Parkinson et al. (1981) found that amniotic fluid copper concentration gradually increased during pregnancy. Copper is essential for development of CNS in embryos (Hefnawy et al.2011). Copper is a component of superoxide dismutase, catalase and cytochrome oxidase and as such plays an important role in oxidation reactions. In addition, by contributing to the formation of ceruloplasmin, copper plays an important role in the absorption and me-tabolism of iron (Lewicka et al.2017). The correlation of its concentration with foetal age and with foetal weight was negative in group II vs IV and groups I, II and IV respectively, although it was non-significant.

The mean concentration of iron decreased significantly in group III of gestation as compared to other groups. It participates in redox reactions, immune processes and DNA synthesis, as well as being a substrate in the synthesis of heme, the main component of hemoglobin (Lewicka et al.2017). The correlation between the concentration of iron and age of fetii was highly significant between group I and group II (Table 3). Negative non significant correlation was observed between its concentration and fetal weight in group I and group III of gestation.

Table 2: $M E A N \pm S E$ values of concentration of various minerals in amniotic fluid of Gaddi sheep.

\begin{tabular}{lcccc}
\hline & \multicolumn{3}{c}{ Age groups } \\
\cline { 2 - 5 } Minerals (units) & $\mathrm{I}(\mathrm{n}=15)$ & $\mathrm{II}(\mathrm{n}=16)$ & $\mathrm{III}(\mathrm{n}=11)$ & $\mathrm{IV}(\mathrm{n}=8)$ \\
\hline Sodium $(\mathrm{mEq} / \mathrm{L})$ & $127.50^{\mathrm{a}} \pm 8.01$ & $123.60^{\mathrm{a}} \pm 7.48$ & $07.90^{\mathrm{a}} \pm 7.91$ & $114.30^{\mathrm{a}} \pm 14.98$ \\
Potassium (mEq/L) & $13.42^{\mathrm{a}} \pm 1.46$ & $07.75^{\mathrm{b}} \pm 1.39$ & $01^{\mathrm{b}} \pm 0.62$ & $10.91^{\mathrm{ab}} \pm 2.10$ \\
Chloride (m mol/L) & $48.37^{\mathrm{a}} \pm 2.65$ & $48.14^{\mathrm{a}} \pm 2.50$ & $50.44^{\mathrm{a}} \pm 0.64$ & $37.60^{\mathrm{b}} \pm 5.26$ \\
Calcium (mg/dl) & $08.35^{\mathrm{a}} \pm 0.83$ & $07.92^{\mathrm{a}} \pm 1.46$ & $09.34^{\mathrm{a}} \pm 1.25$ & $07.19^{\mathrm{a}} \pm 0.76$ \\
Phosphorus (mg/dl) & $02.00^{\mathrm{ab}} \pm 0.47$ & $02.08^{\mathrm{ab}} \pm 0.55$ & $01.63^{\mathrm{a}} \pm 0.45$ & $03.94^{\mathrm{b}} \pm 0.98$ \\
Copper (mg/L) & $00.04^{\mathrm{a}} \pm 0.00$ & $00.03^{\mathrm{a}} \pm 0.00$ & $00.04^{\mathrm{a}} \pm 0.01$ & $00.04^{\mathrm{a}} \pm 0.01$ \\
Iron (mg/L) & $02.28^{\mathrm{a}} \pm 0.63$ & $03.09^{\mathrm{a}} \pm 0.48$ & $00.96^{\mathrm{b}} \pm 0.30$ & $03.11^{\mathrm{a}} \pm 0.78$ \\
Zinc (mg/L) & $00.15^{\mathrm{a}} \pm 0.02$ & $00.09^{\mathrm{a}} \pm 0.02$ & $00.16^{\mathrm{a}} \pm 0.02$ & $00.25^{\mathrm{b}} \pm 0.04$ \\
Magnesium (mg/L) & $08.02^{\mathrm{a}} \pm 1.91$ & $12.51^{\mathrm{ab}} \pm 1.51$ & $11.08^{\mathrm{a}} \pm 1.55$ & $18.08^{\mathrm{b}} \pm 2.93$ \\
\hline
\end{tabular}

Values with same superscripts within a row did not vary significantly $(P<0.05)$. 
Mineral Analysis in the Amniotic Fluid of Gaddi Sheep during Different Stages of Gestation

Table 3: Correlation of coefficient between the concentration of minerals and age of Gaddi sheep foetii.

\begin{tabular}{lccccccc}
\hline & \multicolumn{9}{c}{ Age groups } \\
\cline { 2 - 7 } Minerals & Groupl vs II & Groupl vs III & Groupl vs IV & Groupll vs III & Group II vs IV & GroupIII vs IV \\
\hline Sodium & 0.274 & 0.183 & 0.575 & 0.108 & 0.315 & -0.371 \\
Potassium & 0.375 & 0.104 & 0.286 & $0.869^{* *}$ & -0.331 & -0.604 \\
Chloride & 0.464 & -0.145 & 0.499 & -0.100 & 0.241 & -0.412 \\
Calcium & $0.799^{* *}$ & 0.337 & -0.422 & 0.158 & -0.528 & -0.131 \\
Phosphorus & -0.211 & -0.575 & -0.481 & -0.002 & -0.012 & -0.286 \\
Copper & 0.081 & 0.353 & 0.161 & 0.564 & -0.143 & 0.192 \\
Iron & $0.796^{* *}$ & -0.592 & 0.449 & -0.242 & 0.467 & 0.047 \\
Zinc & -0.018 & $0.694^{*}$ & 0.466 & 0.106 & 0.015 & 0.061 \\
Magnesium & 0.238 & 0.420 & 0.154 & 0.463 & 0.212 & -0.108 \\
\hline
\end{tabular}

*Significant at 5\% $(\mathrm{P}<0.05) ;{ }^{*}$ Significant at $1 \%(\mathrm{P}<0.01)$.

Table 4: Correlation of coefficient between the concentration of minerals and foetal weight of Gaddi sheep.

\begin{tabular}{lcccc}
\hline & \multicolumn{4}{c}{ Age groups } \\
\cline { 2 - 5 } Minerals & Group I & Group II & Group III & Group IV \\
\hline Sodium & -0.025 & $-0.661^{*}$ & -0.306 & 0.075 \\
Potassium & 0.068 & -0.111 & 0.551 & -0.295 \\
Chloride & $0.657^{*}$ & $-0.702^{*}$ & 0.229 & 0.173 \\
Calcium & 0.205 & -0.492 & -0.339 & 0.424 \\
Phosphorus & 0.090 & -0.183 & 0.409 & -0.259 \\
Copper & -0.275 & -0.280 & 0.053 & -0.294 \\
Iron & -0.310 & 0.600 & -0.144 & 0.475 \\
Zinc & 0.581 & -0.102 & -0.597 & 0.193 \\
Magnesium & -0.477 & -0.119 & -0.356 & -0.291 \\
\hline
\end{tabular}

${ }^{*}$ Significant at $5 \%(\mathrm{P}<0.05) ;{ }^{*}$ Significant at $1 \%(\mathrm{P}<0.01)$.

The mean concentration of zinc in the amniotic fluid of Gaddi sheep increased significantly in group IV of gestation as compared to other groups. Zinc has an important function in the body par-ticipating in RNA, DNA and proteins synthesis, as well as playing a role in the stabilization of cell membranes and the skeletal system (lewicka et al.2017). The correlation of its concentration with fetal age was significant between group I and group III. Its concentration was negatively correlated with fetal weight in group II and III of gestation, although the correlation was non-significant. The availability of zinc in forage is not sufficient so its supplementation in forages and concentrates is important to meet the daily requirements of production and reproduction (Farah et al. 2013). Copper, zinc and iron are essential heavy metals and any imbalance in their interactions during pregnancy could have a major impact on fetal growth and development (Olfati et al. 2016).

Magnesium concentration in the amniotic fluid increased significantly from group I to group IV of gestation. Aidasani et al. (1993) found the concentration of magnesium to be $2.53 \pm 0.24 \mathrm{mEq} / \mathrm{L}$ in the amniotic fluid of goat. An optimal level of magnesium in serum is effective in lamb's growth and health and thus prevents the occurrence of diseases related with hypomagnesemia (Olfati et al. 2016). Negative non significant correlation was observed between its concentration and foetal age in group III vs IV (Table 3) and between its concentration and foetal weight throughout gestation (Table 4).

The variation in the concentration of different minerals in amniotic fluid of Gaddi sheep with other studies might be due to several factors such as gestation age, species, breed, rearing and environmental conditions, nutritional status of the animal and the analytical methods use which can affect the composition of the amniotic fluid. Amniotic fluid usually reflects the distribution of the minerals in the body (dam/ fetus) at the moment sample is taken. Their deficiency in dams results in insufficient maternal transfer of these minerals to fetus which can hamper the normal growth and development of fetus (Olfati et al. 2016). Therefore, amniotic fluid can provide important information to a clinician that may not be readily available with blood analysis.

\section{REFERENCES}

Aidasani, R., Chauhan, A.S., Tiwari, S. and Shukla, S.P. (1993). Studies on electrolytes of caprine foetal fluids and foetal serum. Indian Veterinary Journal. 70: 239-241.

Farah, A., Akbar, L.L., Zafar, Q., Ahmad, I. and Riaz, H. (2013). Serum mineral profile in various reproductive phases of mares. Pakistan Veterinary Journa. 33: 296-299.

Gall, C.F., Stier, C.H. and Fraham, K. (1994). Age estimation of goat fetus. Small Ruminant Research. 14: 91- 94.

Hefnawy, A.E., Perez, J.T., Shousha, S.M. and Abukora, S.Y. (2011). Effect of gestation and maternal copper on the fetal fluids and tissues copper concentrations in sheep. American Journal of Animal and Veterinary Sciences. 6: 88-92.

Jalali, L.M. and Koski, K.G. (2018). Amniotic fluid minerals, trace elements and prenatal supplement use in humans emerge as determinants of fetal growth. Journal of Trace Elements in Medicine and Biology. 50: 139-145.

Khadjeh, Gh, H., Ranjbar, R., Salehi, M. and Banan Khojasteh, S.M. (2007). Biochemical evaluation of amniotic fluid during different stages of gestation in the goat. Iranian Journal of Veterinary Research. 8: 266-269.

Lewicka, I., Kocyłowsk,i R., Grzesiak, M., Gaj, Z., Oszukowski, P. and Suliburska, J. (2017). Selected trace elements concentrations in pregnancy and their possible role-literature review. Ginekologia Polska. 88: 509-514. 
Olfati, A., Gholamali, M., Nasreallah, M.K. and Behzad, B. (2016). The relationship between trace mineral concentrations of amniotic fluid with placenta traits in the pregnancy toxaemia Ghezel ewes. Asian Pacific Journal of Reproduction. 5: $321-325$.

Parkinson, C.E., Tan, J.C.Y., Lewis, P.J. and Bennet, M.J. (1981). Amniotic fluid zinc and copper and neural tube defects. Journal of Obstetrics and Gynaecology. 1: 207-212.

Prestes, N.C., Chalhoub, M.C.L., Lopes, M.D. and Takahira, R.K. (2001). Aminocentesis and biochemical evaluation of amniotic fluid in ewes at 70,100 and 145 days of pregnancy. Small Ruminant Research, 39: 277-281.
Shukla, P. and Rajput, R. (2020). Changes in mineral concentration with gestation period in the allantoic fluid of Gaddi sheep. Ruminant Science. 9: 83-86.

Shukla, P., Rajput, R., Kumar, R. and Verma, M. (2019). Biochemical composition of amniotic fluid during different stages of gestation in Gaddi sheep. Indian Journal of Animal Research. 53: 178-180.

Suliburska, J., Kocyłowski, R., Komorowicz, I., Grzesiak, M., Bogdański, P. and Barałkiewicz, D. (2016). Concentrations of mineral in amniotic fluid and their relations to selected maternal and fetal parameters. Biological Trace Element Research.172: 37-45. 